\title{
"PENGARUH KETELADANAN ORANG TUA TERHADAP AKHLAK TERPUJI REMAJA USIA 13-17 TAHUN DI RW 15 KELURAHAN KALIJAGA KECAMATAN HARJAMUKTI KOTA CIREBON"
}

\author{
Oleh: \\ Khusnan, Nurlela, Wawan A. Ridwan \\ Pendidikan Agama Islam (PAI) FITK IAIN Syekh Nurjati Cirebon \\ Email : khusnanhusnand@gmail.com,Nurlela@syekhnurjati.ac.id, \\ wawan.a.ridwan@syekhnurjati.ac.id
}

\begin{abstract}
ABSTRAK
Berdasarkan Studi pendahuluan yang dilakukan di RW 15 Kelurahan Kalijaga, diketahui bahwasannya remaja dianjurkan untuk mengamalkan akhlak mahmudah terhadap orang tua dalam kehidupan sehari-hari sebagai bentuk keteladanan orang tua terhadap remaja. Pembinaan keteladanan orang tua dapat mempengaruhi baik atau buruknya akhalak remaja, karena remaja akan meniru tauladan orang tuanya, orang tua menjadi subjek teladan atau yang menjadikan dirinya sebagai contoh nyata yang dapat di tiru bagi anaknya, apabila orang tua memberi akhlak yang tidak baik maka seorang anak akan menjadi tidak baik, dan sebaliknya apabila orang tua memberi tauladan yang baik maka anakpun akan menjadi baik. akan tetapi dari sekian banyak remaja yang memiliki akhlak mahmudah/ baik terhadap orang tua, akan tetapi masih dapat ditemukan remaja yang kurang memiliki akhlak mahmudah/ baik terhadap orang tua. Seperti masih terdapat sebagian remaja yang melawan orang tua, jarang melaksanakan sholat, bolos mengaji, tidak berjamaah dan lain sebagainya. Tujuan penelitian dalam skripsi ini adalah : 1) Mengetahui apakah keteladanan orang tua di RW 15 Kelurahan Kalijaga Kecamatan Harjamukti Kota Cirebon 2) Mengetahui apakah akhlak terpuji remaja usia 13-17 tahun di RW 15 Kelurahan Kalijaga Kecamatan Harjamukti Kota Cirebon 3) Mengetahui seberapa besar pengaruh keteladanan orang tua terhadap akhlak terpuji remaja usia 13-17 tahun di RW 15 Jurnal Pendidikan Agama Islam IAIN Syekh Nurjati Cirebon


Kelurahan Kalijaga Kecamatan Harjamukti Kota Cirebon Kerangka pemikiran penelitian ini adalah bahwa keteladanan orang tua bertujuan sebagai pembentukan akhlak yang salah satunya adalah akhlak mahmudah terhadap akhlak remaja usia 1317 tahun di RW 15 Kelurahan Kalijaga Kecamatan Harjamukti Kota Cirebon.

Metode yang digunakan dalam penelitian ini adalah kuantitatif. Adapun teknik pengumpulan datanya adalah: 1) Observasi, 2) angket dan 3) dokumentasi, hasil penelitian dengan menggunakan uji korelasi dengan menggunakan perhitungan product moment. Berdasarkan penelitian ini tentang variabel X (keteladanan orang tua) dan variabel Y (akhlak remaja usia 13-17 tahun di RW 15 Kelurahan Kalijaga Kecamatan Harjamukti Kota Cirebon), setelah dibuktikan dan dianalisis dengan hasil persetujuan kategori tinggi dan rendah, korelasi product moment menunjukkan nilai yang positif yaitu 0,631 . Diketahui $r_{\text {hitung }} 0,631$ berada di atas $r_{\text {tabel }}$ sebesar $0,338$. Oleh karena itu, hipotesis di atas secara statistik diterima $\left(\mathrm{H}_{\mathrm{a}}\right)$, yang berarti ada hubungan yang cukup signifikan antara keteladanan orang tua dengan akhlak terpuji remaja usia 13-17 tahun di RW 15 Kelurahan Kalijaga Kecamatan Harjamukti Kota Cirebon.

Kata Kunci: Pengaruh, Keteladanan, Orang Tua

\begin{abstract}
Based on preliminary studies conducted in RW 15 Kalijaga Village, it is known that adolescents are encouraged to practice easy moral towards parents in daily life as a form of parental example of adolescents. Guiding parents' example can influence good or bad for teenagers, because teenagers will imitate the example of their parents, parents become exemplary subjects or who make themselves as real examples that can be copied for their children, if parents give bad character then a child will not be good, and vice versa if the parents give good examples, the child will be good. however, of the many adolescents who have easy / good morals towards their parents, there can still be teenagers who lack easy / good morals towards their

\section{Jurnal Pendidikan Agama Islam} IAINSyekh Nurjati Cirebon


parents. As there are still some teenagers who fight parents, rarely perform prayers, miss recitation, not congregation and so on. The research objectives in this paper are: 1) Knowing whether the exemplary parents in $R W 15$ Kalijaga Village, Harjamukti City, Cirebon City 2) Knowing whether adolescent virtues are aged 1317 years in RW 15 Kalijaga Village Harjamukti District Cirebon City 3) Knowing how much influence parental example of the noble character of adolescents aged 1317 years in RW 15 Kalijaga Sub-District Harjamukti City Cirebon District The rationale for this study is that parental example aims at moral formation, one of which is easy morals towards the morals of adolescents aged 13-17 years in RW 15 Kalijaga Village, Harjamukti District, Cirebon City.

The method used in this study is quantitative. The data collection techniques are: 1) Observation, 2) questionnaire and 3) documentation, the results of the study using a correlation test using product moment calculations. Based on this research about variable $X$ (parental exemplary) and variable $Y$ (morality adolescents aged 1317 years in RW 15 Kalijaga Village District Harjamukti City Cirebon), after being proven and analyzed with the results of approval of high and low categories, product moment correlation shows value the positive is 0,631 . It is known that $r$ counts 0 , 631 is above the table of 0,338. Therefore, the above hypothesis is statistically accepted $(\mathrm{Ha})$, which means there is a significant relationship between the exemplary parents and adolescent's noble character aged 13-17 years in RW 15 Kalijaga Village, Harjamukti District, Cirebon City.

Keywords: Influence, Exemplary, Parents

\section{A. PENDAhuluan}

Menurut Moh. Slamet Untung, keteladanan Nabi Muhammad Saw bukan keteladanan yang absurd dan mustahil dicontoh oleh manusia umumnya. Ketika Nabi Muhammad Saw berinteraksi dengan Allah sang Khaliq, dengan sesama manusia dan dengan lingkungan, semuanya terdapat keteladanan yang dapat

\footnotetext{
Jurnal Pendidikan Agama Islam
} IAIN Syekh Nurjati Cirebon 
dijadikan sebagai bahan inspirasi moral bagi seseorang untuk melakukan hal yang sama. Interaksi edukatif yang dilakukan oleh Nabi Muhammad Saw ini selanjutnya dapat dirumuskan dengan: akhlak manusia terhadap Allah, akhlak manusia dengan dirinya sendiri, akhlak manusia dengan manusia lainnya, dan akhlak manusia dengan lingkungan. ${ }^{1}$ Metode atau cara yang paling efektif dalam menanamkan prinsip-prinsip ajaran dan nilai-nilai akhlak pada anak adalah dengan memberikan contoh. Sebagaimana yang diungkapkan Abdullah Ulwan sebagai berikut "Keteladanan dalam pendidikan adalah suatu metode yang paling ampuh dan efektif dalam mempersiapkan dan membentuk anak secara moral, individu dan sosial". ${ }^{2}$ Tanggung jawab orang tua dalam mendidik anak hendaklah terusmenerus dilakukan, hingga anak tersebut benar-benar matang pribadinya dan mencapai kedewasaan. Namun saat anak masih dalam usia remaja awal (13-17 tahun), biasanya anak akan mengalami masa kegoncangan. Fase remaja adalah masa peralihan dari kanak-kanak menjadi dewasa, masa pencarian identitas diri sehingga ia akan mudah sekali dipengaruhi. ${ }^{3}$

Berdasarkan hasil pengamatan observasi yang peneliti peroleh pada hari senin, 24 Juni 2018 berkaitan dengan perkembangan akhlak terpuji remaja di RW 15 Kelurahan Kalijaga kecamatan Harjamukti Kota Cirebon, sampel khususnya remaja, bahwa mayoritas remaja usia 13-17 memiliki akhlak yang kurang baik, seperti ketika berangkat sekolah tidak bersalaman kepada orang tua, mengabaikan waktu sholat dan ngaji, mereka cenderung mengobrol dengan teman, bermain gadget dan bahkan yang lebih mengkhawatirkan ada remaja yang melawan orang tua ketika ia diberi nasehat ataupun ketika ditegur karna kesalahan yang ia perbuat sendiri, remajaputra/putri pun masih banyak menggunakan perkataan yang tidak sopan ketika berbicara dengan kawannya maupun dengan orang tuanyaa sendiri,

\footnotetext{
${ }^{1}$ Moh. Slamet Untung, Muhammad Sang Pendidik (Semarang : Pustaka Rizki Putra, 2005), 160.

${ }^{2}$ Abdullah Ulwan, Tarbiyatul Aulad fi al-Islam, Juz. II (Beirut: Dar as Salam, 1893), 633.

${ }^{3}$ Endang Purwanti dan Nur Widodo, Perkembangan Peserta Didik (Malang: UMM Press, 2000), 106.

Jurnal Pendidikan Agama Islam IAIN Syekh Nurjati Cirebon 
sehingga akhlak terpuji remaja perlu perhatian khusus untuk dibina menjadi lebih baik dalam kehidupan sehari-hari. Berdasarkan hasil observasi dan wawancara yang dilakukan dengan dengan Pak Kurniadi selaku ketua RW 15 Kelurahan Kalijaga Kecamatan Harjamukti Kota Cirebon. Mengemukakan, bahwa keteladanan orang tua di lingkungan ini dikategorikan baik, hal ini dapat dilihat dari kegiatan keagamaan, seperti sholat berjamaah, pengajian, dll. Keteladanan orang tua tersebut selain karena dipengaruhi oleh lingkungan sekitar, akan tetapi masih ada beberapa remaja yang masih kurang memiliki akhlak terpuji diantaranya masih ada remaja yang melawan orang tua, masih ada remaja yang tidak melaksanakan sholat, masih ada remaja yang nongkrong ketika masuk waktu sholat, malas mengaji, dan lain-lain. Uraian diatas dan kenyataan yang dijumpai selama penulis melakukan studi pendahuluan, didapati permasalahan bahwa keteladanan orang tua dikategorikan baik. Akan tetapi, akhhlak terpuji remaja usia 13-17 tahun di RW 15 Kelurahan Kalijaga Kecamatan Harjamukti Kota Cirebon masih kurang.

\section{B. LANDASAN TEORI}

\section{Pengaruh Keteladanan Orang Tua}

Bahasa Arab keteladanan diungkapkan dengan kata uswahdan qudwah. Menurut Ar-Raghib Al-Ashfahani, sebagaimana dikutip Thomas Patrik Hughes 1982:657 dalam bukunya Dictionary of Islam, uswahdiartikan an example, “ is condition in which a man is in respect of another's imitating him"..Artinya teladan adalah suatu keadaan seseorang dihormati oleh orang lain yang meneladaninya. Pengertian Al-Ashfahani ini terkesan lebih luas karena keadaan ini bisa dalam hal kebaikan, kejelekan, kejahatan, atau kemurtadan. ${ }^{4}$

\footnotetext{
${ }^{4}$ Arief Armai, Pengantar Ilmu dan Metodologi Pendidikan Islam (Jakarta: Ciputat Press, 2002), 117.

Jurnal Pendidikan Agama Islam IAIN Syekh Nurjati Cirebon 
Menurut Abuddin Nata kata uswah terdapat dalam Al-Qur'an dengan diberi sifat dibelakangnya dengan sifat hasanah yang berarti baik. Sehingga terdapat ungkapan uswatun hasanah yang berarti teladan yang baik. ${ }^{5}$

Orang tua adalah ayah dan ibu kandung, atau orang yang dianggap tua atau dituakan (cerdik, pandai, ahli dan sebagainya), atau orang-orang yang dihormati. dan disegani.Dalam Islam orang tua ditempatkan pada posisi tertinggi sehubungan dengan kasih sayang dan ketulusan oleh anak-anak mereka. ${ }^{6}$

\section{Akhlak Terpuji Remaja}

Akhlak menurut bahasa berasal dari bahasa arab akhlaq bentuk jamakdari alkhuluq yang berarti: (1) tabiat, budi pekerti, (2) adat kebiasaan, (3) keperwiraan, kesatriaan, kejantanan, (4) Agama, dan (5) kemarahan (al-gadab). ${ }^{7}$

Akhlak mahmudah disebut juga sebagai akhlak terpuji. Akhlak terpuji erat kaitannya dengan kebaikan atau perbuatan baik. Menurut Ali bin Abi Thalib akhlak terpuji adalah:"Sesuatu yang baik memiliki pengertian menjauhkan diri dari larangan, mencari sesuatu yang halal dan memberikan kelonggaran pada keluarga". 8

Remaja secara etimologi disebut Adolescence berasal dari bahasa Latin Adolescere yang berarti remaja, artinya tumbuh atau tumbuh mencapai dewasa. Remaja menurut Zakiah Daradjat adalah tahap peralihan dari masa anak-anak, tetapi belum dipandang dewasa.Remaja adalah umur yang menjembatani antara umur anak-anak dan umur dewasa. ${ }^{9}$

\footnotetext{
${ }^{5}$ Abuddin Nata, Filsafat Pendidikan Islam (Jakarta: Logos Wacana Ilmu, 1997), 95.

${ }^{6}$ Abuddin Nata, Pendidikan dalam Perspektif Hadis (Jakarta: UIN Press, 2005), 233.

${ }^{7}$ Kafrawi Ridwan (eds.), Ensiklopedi Islam (Jakarta: Ichtiar Baru Van Hoeve, 1997), 102.

${ }^{8}$ Muhammad Sayoti, Ilmu Akhlak (Bandung: Lisan, 1987), 38.

${ }^{9}$ Aat Syafaat dkk, Peran Pendididkan Islam dalam Mencegah Kenakalan Remaja (Jakarta: Rajawali, 2018), 87.
}

Jurnal Pendidikan Agama Islam IAIN Syekh Nurjati Cirebon 


\section{METODOLOGI DAN PENELITIAN}

\section{Teknik Pengumpulan Data}

a. Observasi

Menurut Sutrisno Hadi (1986) Observasi merupakan suatu proses yang kompleks, suatu proses yang tersusun dari berbagai proses biologis dan psikologis.

Teknik ini dilakukan untuk mengumpulkan informasi. Pengamatan dilakukan dengan mengamati proses bimbingan keteladanan orang tua terhadap Akhlak remaja usia 13-17 tahun, di RW 15, Kecamatan Harjamukti, Kota Cirebon.

b. Dokumentasi

Metode ini merupakan cara atau teknik memperoleh data mengenai halhal atau variabel yang berupa catatan, transkip, buku, surat kabar, majalah, prasasti, notulen rapat, agenda dan sebagainya. Merupakan suatu teknik pengumpulan data dengan menghimpun dan menganalisis dokumen baik tertulis, gambar maupun elektronik.

c. Angket

Senada dengan penjelasan diatas, Sugiyono menjelaskan bahwa: Kuesioner (Angket) merupakan teknik pengumpulan data yang dilakukan dengan cara memberi seperangkat pertanyaan atau pernyataan tertulis kepada responden untuk dijawabnya. ${ }^{10}$

\footnotetext{
${ }^{10}$ Sugiyono, Metode Penelitian Pendidikan (Bandung. Alfabeta, 2016), 199.
}

Jurnal Pendidikan Agama Islam 


\section{PEMBAHASAN}

\section{Pengaruh keteladanan Orang Tua}

Menurut Kartini Kartono, keteladanan sama dengan modeling, yaitu bentuk pembelajaran seseorang bagaimana melakukan suatu tindakan dengan memperhatikan dan meniru sikap serta tingkah laku orang lain. ${ }^{11}$

Dari beberapa definisi diatas dapat disimpulkan bahwa keteladanan adalah hal-hal yang dapat ditiru, diikuti, atau dicontoh dariseseorang. Namun keteladanan yang dimaksud di sini adalah keteladanan yang dapat dijadikan sebagai metode pendidikan, yaitu keteladanan yang baik yang sesuai dengan pengertian uswahdalam ayatayat al-Qur'an.

Keteladanan dalam penelitian ini adalah keteladanan akhlak orang tua, sehingga pengertiannya adalah akhlak-akhlak yang baik, yang dapat ditiru, diikuti atau dicontoh dari orang tua.

a. Dasar Keteladanan

Manusia pada dasarnya diberikan kemampuan untuk meniru dan mengikuti dalam bertingkahlaku. Terlebih bagi anak yang masih memerlukan arahan dan petunjuk dalam berbuat sesuatu. Anak akan melihat dan mengamati segala bentuk sikap yang dia temui.

Apabila kita mencermati sistem pendidikan Nabi Muhammad Saw, maka keteladanan merupakan metode yang paling mendominasi metode lainnya, terutama dalam bidang akhlak. Beliau selalu lebih dulu mempraktekkan semua ajaran dari Allah, sebelum menyampaikannya kepada umat. ${ }^{12}$

Metode atau cara yang paling efektif dalam menanamkan prinsipprinsip ajaran dan nilai-nilai akhlak pada anak adalah dengan memberikan contoh. Sebagaimana yang diungkapkan Abdullah Ulwan sebagai berikut

${ }^{11}$ Kartono kartini, Kamus Psikologi (Bandung: Satelit, 1987), 285.

${ }^{12}$ Moh. Slamet Untung, Muhammad Sang Pendidik. 153.

Jurnal Pendidikan Agama Islam IAIN Syekh Nurjati Cirebon 
"Keteladanan dalam pendidikan adalah suatu metode yang paling ampuh dan efektif dalam mempersiapkan dan membentuk anak secara moral, individu dan sosial". ${ }^{13}$

Dalam ajaran Islam Allah swt, sebagai peletak manhaj langit sekaligus sebagai mukjizat bagi hamba-hamba piliahan-Nya. Seorang Rasul yang diutus untuk menyampaikan risalah langit kepada umat haruslah disifati dengan kesempurnaan jiwa, akhlak dan akal yang tinggi. Sehingga orangorang dapat menjadikannya rujukan, mengikutinya, belajar, dan mencontohnya dalam kemuliaan dan ketinggian akhlak. Karenanya Allah mengutus Nabi Muhammad saw untuk menjadi teladan yang baik sepanjang sejarah untuk muslimin dan seluruh umat manusia.Allah swt berfirman:

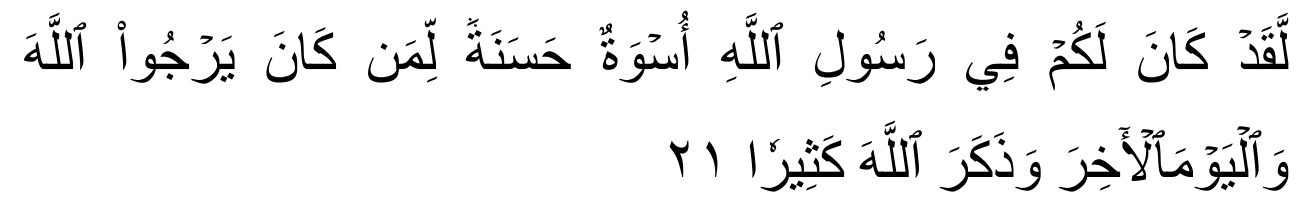

Artinya: "Sesungguhnya telah ada pada (diri) Rasulullah itu suri teladan yang baik bagimu (yaitu) bagi orang yang mengharap (rahmat) Allah dan (kedatangan) hari kiamat dan dia banyak menyebut Allah".(Q.S. Al-Ahzab ayat 21$).{ }^{14}$

Demikian teladan yang diajarkan Rasulullah, maka dapat dipastikan adanya kekuatan yang muncul dalam jiwa para sahabat melihat kesungguhan rasul-Nya. Keadaan yang membawa semangat juang tinggi yang akan berpengaruh ke dalam jiwa-jiwa kaum muslimin. Kekuatan keimanan yang akan mewarnai jiwa umat Islam akan pentingnya menggelorakan semangat, rela berkorban, yakin dan memiliki jiwa perkasa. Dalam hal ini Rasulullah sebagai pemimpin dan pendidik memberikan

${ }^{13}$ Abdullah Ulwan, Tarbiyatul Aulad 633.

${ }^{14}$ Ulwan Abdullah Nashih, Pendidikan Anak dalam Islam (Solo: Insan Kamil, 2013), 516.

Jurnal Pendidikan Agama Islam IAIN Syekh Nurjati Cirebon 
contoh dalam perbuatan nyata bukan hanya berbentuk perintah kepada para sahabatnya dalam bersungguh-sungguh menggali parit sebagai benteng pertahanan kaum muslimin. Oleh karena itu suah seharusnya pendidik mencontohkan ssikap nyata dalam menjalankan kebaikan. Bukan sebaliknyamemberikan perintah dan intruksi belaka. Tidak diiringi dengan sikap langsung dan bersegera dalam menjalankannya. Sebab bisa beraujung pada kemalasan dan sikap acuh anak saat mendengar kebaikan. Dikarenakan orang tuanya sebagai pendidik tidak mengamalkan secara langsung dengan perbuatan.

b. Bentuk-bentuk Keteladanan

Bentuk-bentuk keteladanan ada dua, yaitu:

1) Keteladanan yang disengaja

Ialah keteladanan yang memang disertai penjelasan atau perintah agar meneladani, atau bentuk peneladanan yang memangdiupayakan secara sengaja, seperti seorang bapak yang mengajak serta anaknya melaksanakan sholat berjamaah di Masjid, dan seorang imam yang membaguskan shalatnya untuk mengerjakan sholat yang sempurna.

Dalam hal ini Rasulullah Saw telah memberikan teladan langsung kepada para sahabat sehingga mereka telah banyak mempelajari masalah keagamaan dengan mengikuti teladan yang sengaja diberikan Rasulullah Saw.

2) Keteladanan yang tidak disengaja

Ialah keteladanan yang terjadi secara langsung dengan memperhatikan pribadi sosok yang diikuti, baik dalam keilmuan, kepemimpinan, sifat dan keikhlasan.

Pengaruh keteladanan ini terjadi secara spontan dan tidak sengaja, ini berarti bahwa setiap orang yang diharapkan menjadi 
teladan hendaknya memelihara tingkah lakunya, disertai kesadaran bahwa ia bertangggung jawab di hadapan Allah dalam segala hal yang diikuti oleh orang lain, khususnya anak-anaknya. ${ }^{15}$ (Ahmad Tafsir, 1994, hlm. 143-144).

c. Aspek-aspek Keteladanan

Menurut Muhammad Daud Ali, akhlak terbagi menjadi dua, yaitu: pertama, akhlak terhadap Allah atau Khaliqdan kedua, akhlak terhadap makhluk (semua ciptaan Allah).Akhlak terhadap makhluk terbagi menjadi dua yaitu (1) Akhlak terhadap manusia, yaitu: (a) diri sendiri, (b) sesama manusia lainnya (Rasulullah, keluarga, karib kerabat, tetangga dan masyarakat). (2) Akhlak terhadap bukan manusia, yaitu makhluk lain seperti hewan, tumbuh-tumbuhan, alam dan lingkungan sekitar. ${ }^{16}$

Akhlak diatas merupakan akhlak-akhlak yang harus diteladankan oleh orang tua kepada anaknya dalam usaha menanamkan akhlak muliaanak mereka. Aspek-aspek keteladanan yang dibahas dalam penelitian ini, yaitu:

1) Keteladanan terhadap Allah, meliputi antara lain:

a) Takwa kepada Allah Swt

b) Cinta dan Ridla kepada-Nya

c) Bersyukur atas nikmat-Nya

d) Tawakal

2) Keteladanan terhadap diri sendiri, diantaranya:

a) Jujur dan dapat dipercaya

b) Rendah Hati

\footnotetext{
${ }^{15}$ Ahmad Tafsir, "Pentingnya Pendidikan Agama dalam Keluarga", dalam Ahmad tafsir (ed), Pendidikan Agama dalam Keluarga (Bandung: Remaja Rosdakarya, 2000), 143-144.

${ }^{16}$ Muhammad Daud Ali, Pendidikan Agama Islam (Jakarta: Raja Grafindo Persada, 2000), 352.

Jurnal Pendidikan Agama Islam IAIN Syekh Nurjati Cirebon 
c) Kerja Keras dan Disiplin

d) Berjiwa Ikhlas

e) Sabar

f) Hidup Bersih dan Sehat

3) Keteladanan terhadap sesama manusia, dibagi menjadi:

a) Akhlak terhadap keluarga, karib kerabat, diantaranya: saling menyayangi, berbuat baik, membina silaturahim.

b) Akhlak terhadap tetangga, masyarakat, diantaranya: saling menghormati, tolong menolong, gotong royong.

4) Keteladanan terhadap lingkungan, yaitu:

a) Memelihara kelestarian lingkungan

b) Menjaga kebersihan lingkungan

c) Menyayangi makhluk hidup

\section{Akhlak Terpuji Remaja}

Abuddin Nata menambahkan bahwa perbuatan itu dapat disebut akhlak (khususnya akhlak yang baik) apabila perbuatan itu dilakukan dengan ikhlas semata-mata karena Allah, bukan karena mengharapkan pujian dari orang lain. $^{17}$

Istilah akhlak itu sendiri masih bersifat netral, belum menunjuk kepada halhal yang baik atau buruk.Namun apabila akhlak itu disebut tersendiri, tidak dirangkai dengan sifat tertentu, maka yang dimaksud adalah yang mulia.Misalnya, seseorang mengatakan, 'kamu benar-benar anak berakhlak", maka maksudnya adalah kamu benarbenar mempunyai akhlak yang baik.

Ruang lingkup akhlak adalah sama dengan ruang lingkup ajaran Islam itu sendiri, yaitu pola hubungan manusia dengan Allah (khaliq) dan hubungan

${ }^{17}$ Nata Abuddin, Pendidikan dalam Perspektif Hadis.. 6.

Jurnal Pendidikan Agama Islam IAIN Syekh Nurjati Cirebon 
dengan sesama makhluk (baik manusia maupun bukan manusia). Sehingga apabila di perinci sebagai berikut:

a. Akhlak terhadap makhluk, terbagi dua:

1) Akhlak terhadap manusia, dapat dibagi lagi menjadi: Akhlak terhadap diri sendiri dan akhlak terhadap orang lain atau sesama manusia (Rasulullah, keluarga, teman /karib kerabat, tetangga, masyarakat).

2) Akhlak terhadap bukan manusia, yaitu: alam/lingkungan (hewan, tumbuh-tumbuhan dan alam sekitar).

Sehubungan dengan hal tersebut diatas penelitian ini hanya memfokuskan pembahasan mengenai akhlak yang berhubungan denganAllah Swt, akhlak terhadap diri sendiri, terhadap sesama manusia, dan terhadap lingkungan.

b. Akhlak terhadap Allah

Yang dimaksud dengan akhlak terhadap Allah atau pola hubungan manusia dengan Allah Swt, adalah sikap atau perbuatan yang seharusnya dilakukan oleh manusia sebagai makhluk kepada Allah Swt sebagai khaliq. Titik tolak akhlak terhadap Allah adalah pengakuan dan kesadaran bahwa tiada Tuhan melainkan Allah.

Sekurang-kurangnya ada empat alasan mengapa manusia perlu berakhlak kepada Allah. Pertama,karena Allah yang telah menciptakan manusia. Kedua,karena Allah yang telah memberikan perlengkapan panca indera, akal pikiran dan hati sanubari, disamping tubuh yang kokoh dan sempurna kepada manusia. Ketiga,karena Allah yang telah menyediakan berbagai bahan dan sarana yang diperlukan bagi kelangsungan hidup manusia. Keempat, Allah yang telah memuliakan manusia dari makhluk Allah lainnya.

Banyak sekali cara yang dapat dilakukan dalam berakhlak kepada Allah. Dalam hal ini akhlak-akhlak yang perlu ditanamkan oleh orang tua,

\section{Jurnal Pendidikan Agama Islam IAIN Syekh Nurjati Cirebon}


terutama dengan cara diteladankan kepada anak-anaknya dalam hubungannya dengan akhlak terhadap Allah, antara lain:

1) Takwa

Bertakwa kepada Allah, seperti: menunaikan shalat fardlu 5 waktu, menunaikan puasa pada bulan Ramadlan dan menjauhi semua yang dilarang-Nya, seperti: tidak berjudi dan sebagainya.

2) Cinta dan Ridla

Salah satu cara mencintai Allah adalah dengan selalu berdzikir dan mengingat-Nya, memperbanyak doa dan membaca al-Qur`an.

3) Bersyukur

Bersyukur atas nikmat Allah tidak hanya diucapkan dengan lisan, akan tetapi juga diwujudkan dengan perbuatan, yaitu dengan menggunakan nikmat yang telah diberikan Allah dengan sebaikbaiknya.

4) Tawakal

Tawakal kepada Allah berarti menyerahkan semua urusan kita sepenuhnya kepada-Nya, sesudah melakukan usaha semaksimal yang kita sanggupi, sehingga kita benar-benar tidak mencampurinya lagi. ${ }^{18}$

c. Akhlak terhadap diri sendiri

Akhlak terhadap diri sendiri adalah pemenuhan kewajiban manusia terhadap dirinya sendiri, baik yang menyangkut jasmani maupun rohani. Akhlak ini meliputi:

1) Jujur dan dapat dipercaya

2) Rendah Hati

3) Kerja keras dan Disiplin

4) Berjiwa Ikhlas

18 Abuddin Nata, Pendidikan dalam Perspektif Hadis. 6

Jurnal Pendidikan Agama Islam IAIN Syekh Nurjati Cirebon 
5) Sabar

6) Hidup bersih dan sehat. ${ }^{19}$

d. Akhlak terhadap sesama manusia, antara lain:

1) Akhlak terhadap keluarga, kerabat; saling menyayangi, berbuat baik, membina silaturahim.

2) Akhlak terhadap tetangga, masyarakat: saling menghormati, tolong menolong, dan gotong royong. ${ }^{20}$ (Muhammad Daud Ali, 2000,hlm. 357-358).

e. Akhlak terhadap lingkungan (hewan, tumbuh-tumbuhan, alam sekitar).

Akhlak terhadap lingkungan yang diajarkan al-Quran bersumber dari fungsi manusia sebagai khalifah di Bumi. Cara berakhlak terhadap lingkungan diantaranya: memelihara kelestarian lingkungan, menjaga kebersihan lingkungan, dan menyayangi makhluk hidup. ${ }^{21}$

Tabel $1^{22}$

Skala Likert

\begin{tabular}{|c|c|}
\hline Alternatif Jawaban & Skor \\
\hline Selalu & 4 \\
\hline Sering & 3 \\
\hline Kadang-kadang & 2 \\
\hline Tidak Pernah & 1 \\
\hline
\end{tabular}

Di dalam penelitian terdapat instrumen, yaitu:

1. Definisi konseptual

${ }^{19}$ Junaedi Mahfudz, (ed.), Aqidah Akhlak untuk Madrasah Aliyah kelas X (Semarang: CV.Ghani \& SON bekerjasama dengan Kanwil Depag Jateng, 2004), 16-18.

${ }^{20}$ Muhammad Daud Ali, Pendidikan Agama Islam.............., 357-358.

${ }^{21}$ Abuddin Nata, Filsafat Pendidikan Islam, ........................... 152

${ }^{22}$ Sugiyono, Metode Penelitian Pendekatan Kuantitatif, Kualitatif, dan R\&D (Bandung: Alfabeta, 2013), 199.

Jurnal Pendidikan Agama Islam IAIN Syekh Nurjati Cirebon 
a. Keteladanan Orang Tua

Keteladanan adalah hal-hal yang dapat ditiru, diikuti, atau dicontoh dariseseorang. Namun keteladanan yang dimaksud di sini adalah keteladanan yang dapat dijadikan sebagai metode pendidikan, yaitu keteladanan yang baik yang sesuai dengan pengertian uswah dalam ayatayat al-Qur'an.

Aspek-aspek keteladanan yang dibahas dalam penelitian ini, yaitu: Keteladanan terhadap Allah, Keteladanan terhadap diri sendiri, Keteladanan terhadap sesama manusia, Keteladanan terhadap lingkungan.

b. Akhlak Remaja

Akhlak adalah suatu perilaku atau kepribadian seseorang yang melaksanakan perintah Allah Swt dan menjauhi segala larangan-Nya, karena akhlak yang baik adalah akhlak yang harus mesti melekat pada tiap-tiap manusia.

Macam-macam akhlak mahmudah remaja diantaranya: Husnudzon (baik sangka), Tawakal, Shidqu (Jujur), Sabar, Iffah (Memelihara Kesucian Diri), Bijaksana, Ihsan.

2. Definisi operasional

a. Keteladanan Orang Tua

Keteladanan adalah hal-hal yang dapat ditiru, diikuti, atau dicontoh dariseseorang. Namun keteladanan yang dimaksud di sini adalah keteladanan yang dapat dijadikan sebagai metode pendidikan, yaitu keteladanan yang baik yang sesuai dengan pengertian uswah dalam ayatayat al-Qur'an.

Tingkat keteladanan Orang Tua tersebut diperoleh melalui penilaian yang dinyatakan dari hasil skor jawaban angket yang disebarkan kepada Ibu-ibu/Orang Tua RW 15

b. Akhlak Remaja

Jurnal Pendidikan Agama Islam 142 IAINSyekh Nurjati Cirebon 
Akhlak adalah suatu perilaku atau kepribadian seseorang yang melaksanakan perintah Allah Swt dan menjauhi segala larangan-Nya, karena akhlak yang baik adalah akhlak yang harus mesti melekat pada tiap-tiap manusia.

Akhlak Remaja tersebut diperoleh melalui penilaian yang dinyatakan dari hasil skor jawaban angket yang disebarkan kepada Remaja RW 15.

\section{Tabel 2}

Kisi kisi penelitian

\begin{tabular}{|c|c|c|c|c|}
\hline No & Variabel & Indikator & Skala & $\begin{array}{c}\text { No. } \\
\text { Angket }\end{array}$ \\
\hline 1. & $\begin{array}{l}\text { Pengaruh } \\
\text { Keteladanan } \\
\text { Orang Tua }\end{array}$ & $\begin{array}{l}\text { 1. Keteladanan terhadap Allah } \\
\text { 2. Keteladanan terhadap diri } \\
\text { sendiri } \\
\text { 3. Keteladanan terhadap } \\
\text { sesama manusia } \\
\text { 4. Keteladanan terhadap } \\
\text { lingkungan }\end{array}$ & Likert & $\begin{array}{c}6-10 \\
11-15 \\
16-20\end{array}$ \\
\hline 2. & $\begin{array}{l}\text { Akhlak } \\
\text { Remaja }\end{array}$ & $\begin{array}{l}\text { 1. Husnudzon (baik sangka) } \\
\text { 2. Tawakal } \\
\text { 3. Shidqu (Jujur) } \\
\text { 4. Sabar } \\
\text { 5. Iffah (Memelihara Kesucian } \\
\text { Diri) } \\
\text { 6. Bijaksana } \\
\text { 7. Ihsan }\end{array}$ & & $\begin{array}{c}1-3 \\
4-6 \\
7-9 \\
10-12 \\
13-15 \\
16-18 \\
19-20\end{array}$ \\
\hline
\end{tabular}

\section{Teknik Analisis Data}

Analisis data adalah proses penyederhanaan kedalam bentuk yang lebih mudah dibaca dan diinterpretasikan. Tujuan analisis data dalam penelitian ini 
adalah untuk membatasi penemuan-penemuan sehingga menjadi satu data yang teratur serta tersusun lebih berarti sehingga mudah dipahami, bukan hanya oleh penulis tetapi juga oleh orang lain yang ingin mengetahui hasil penelitian ini.

\section{Uji Variabel}

Teknik analisis data yang digunakan dalam penelitian ini ialah menganalisis pervariabel dengan menggunakan buku Suharsimi Arikunto (2006: 253) yaitu menghitung rata-rata perindikator dan membandingkan peritem pernyataan angket. Apakah berada di atas nilai rata-rata indikator atau di bawah nilai indikator, ketika di bawah dinyatakan rendah, ketika di atas dinyatakan tinggi.

\section{Uji Korelasi}

Korelasi yaitu suatu alat statistik, yang dapat digunakan untuk mencari hubungan antara dua variabel yang berbeda agar dapat menentukan tingkat hubungan antara variabel-variabel dengan rumus sebagai berikut:

$$
r_{x y}=\frac{N \sum x y-\left(\sum x\right)\left(\sum y\right)}{\sqrt{\left\{N \sum x^{2}-\left(\sum x\right)^{2}\right)\left\{N \sum y^{2}-\left(\sum y\right)^{2}\right\}}}
$$

\section{Keterangan :}

$\mathrm{r}_{\mathrm{xy}}=$ Koefisien korelasi antara $\mathrm{X}$ dan $\mathrm{Y}$

$\mathrm{N}=$ Jumlah sampel

$\sum X Y=$ Jumlah hasil perkalian antara skor $\mathrm{X}$ dan skor $\mathrm{Y}$

$\sum X \quad=$ Jumlah seluruh skor item

$\sum Y=$ Jumlah skor total.

$\sum x^{2}=$ Jumlah kuadrat skor item.

$\sum y^{2}=$ Jumlah kuadrat skor total. ${ }^{23}$

${ }^{23}$ Anas Sudijono, Pengantar Evaluasi Pendidikan (Jakarta: Raja Grafindo Persada, 2012), 193.

Jurnal Pendidikan Agama Islam

IAIN Syekh Nurjati Cirebon 
Selanjutnya untuk memberikan interpretasi secara sederhana angka indeks korelasi " $\mathrm{r}$ " product moment $\left(\mathrm{r}_{\mathrm{xy}}\right)$ diperlukan pedoman sebagai berikut

\section{Hipotesis Statistik}

Subana dkk. menerangkan bahwa salah satu ciri penelitian pendidikan yang berjenis kuantitatif adalah adanya keberadaan hipotesis. Hipotesis adalah dugaan mengenai suatu hal yang dibuat untuk menjelaskan hal yang sering dituntut untuk melakukan pengecekan. ${ }^{24}$ Dalam hal ini yang menjadi hipotesis awal (H0) dan hipotesis alternative (H1) adalah:

1. Ha : terdapat pengaruh keteladanan orang tua terhadap akhlak terpuji remaja usia 13-17 tahun di RW 15 kelurahan kalijaga kecamatan harjamukti kota cirebon

Ho : tidak terdapat pengaruh keteladanan orang tua terhadap akhlak terpuji remaja usia 13-17 tahun di RW 15 kelurahan kalijaga kecamatan harjamukti kota cirebon

Berdasarkan penelitian ini tentang variabel $\mathrm{X}$ (keteladanan orang tua) dan variabel Y (akhlak remaja usia 13-17 tahun di RW 15 Kelurahan Kalijaga Kecamatan Harjamukti Kota Cirebon), setelah dibuktikan dan dianalisis dengan hasil persetujuan kategori tinggi dan rendah, korelasi product moment menunjukkan nilai yang positif yaitu 0,631 . Diketahui $r_{\text {hitung }} 0,631$ berada di atas $r_{\text {tabel }}$ sebesar 0,338 . Oleh karena itu, hipotesis di atas secara statistik diterima $\left(\mathrm{H}_{\mathrm{a}}\right)$, yang berarti ada hubungan yang cukup signifikan antara keteladanan orang tua dengan akhlak terpuji remaja usia 13-17 tahun di RW 15 Kelurahan Kalijaga Kecamatan Harjamukti Kota Cirebon.

${ }^{24}$ Subana dkk, Statistik Pendidikan (Bandung Pustaka, 2000), 112.

Jurnal Pendidikan Agama Islam IAIN Syekh Nurjati Cirebon 


\section{E. KESIMPULAN}

Berdasarkan hasil penelitian tentang keteladanan orang tua dengan akhlak remaja di RW 15 Kelurahan Kalijaga Kecamatan Harjamukti Kota Cirebon yang telah dilakukan dapat disimpulkan ke dalam tiga poin yakni:

1. Keteladanan orang tuadi RW 15 Kelurahan Kalijaga Kecamatan Harjamukti Kota Cirebon tergolong kategori Baik berdasarkan perhitungan angket yang dilakukan oleh peneliti yaitu dengan hasil rata-rata sebesar 3,26 dengan nilai $81,5 \%$ karena berada pada interval $81 \% 100 \%$

2. Akhlak Remaja di RW 15 Kelurahan Kalijaga Kecamatan Harjamukti Kota Cirebon tergolong kategori cukup baik. Hal iniberdasarkan perhitungan angket yang dilakukan oleh peneliti yaitu dengan hasil rata-rata sebesar 3,16dengan nilai $79 \%$ karena berada pada interval $60 \% 80 \%$.

3. Pengaruh keteladanan orang tua dengan akhlak remaja di RW 15 Kelurahan Kalijaga Kecamatan Harjamukti Kota Cirebon memiliki tingkat korelasi tinggi. Hal ini dapat dibuktikan dari perhitungan koefisien korelasi dengan nilai 0,631 yang berada pada terdapat pada nilai 0,60-0,799,dengan prosentase sebesar 39,81\%termasuk kategori kurang, sedangkan sisanya sebesar 60,19\% dipengaruhi oleh faktor lain yang tidak peneliti teliti dan dapat mempengaruhi akhlak remaja, seperti faktor lingkungan, bimbingan dari orang tua, lingkungan di luar,kurang perhatian dan sebagainya.

\section{DAFTAR PUSTAKA}

Aat Syafaat dkk, 2018. Peran Pendididkan Islam dalam Mencegah Kenakalan Remaja. Jakarta: Rajawali.

Abdullah Nashih, Ulwan, 2013. Pendidikan Anak dalam Islam, Solo: Insan Kamil. Ali, Muhammad Daud, 2000. Pendidikan Agama Islam, Jakarta: Raja Grafindo Persada. 
Ali, Muhammad Daud, 2000. Pendidikan Agama Islam, Jakarta: Raja Grafindo Persada.

Armai Arief, 2002. Pengantar Ilmu dan Metodologi Pendidikan Islam, Jakarta: Ciputat Press.

Endang Purwanti dan Nur Widodo, 2000. Perkembangan Peserta Didik, Malang: UMM Press.

Junaedi Mahfudz, (ed.), 2004. Aqidah Akhlak untuk Madrasah Aliyah kelas X, Semarang: CV.Ghani \& SON bekerjasama dengan Kanwil Depag Jateng.

Kartono kartini, 1987. Kamus Psikologi, Bandung: Satelit.

Nata Abuddin, 1997. Filsafat Pendidikan Islam, Jakarta: Logos Wacana Ilmu.

Nata Abuddin, 2005. Pendidikan dalam Perspektif Hadis, Jakarta: UIN Press.

Ridwan, Kafrawi (eds.), 1997. Ensiklopedi Islam, Jakarta: Ichtiar Baru Van Hoeve.

Sayoti, Muhammad. (1987). Ilmu Akhlak. Bandung: Lisan.

Subana, dkk, 2000. Statistik Pendidikan. Bandung Pustaka Setia.

Sudijono, Anas. 2012. Pengantar Evaluasi Pendidikan. Jakarta: Raja Grafindo Persada.

Sugiyono. 2016. Metode Penelitian Pendidikan. Bandung. Alfabeta.

Sugiyono. 2013. Metode Penelitian Pendekatan Kuantitatif, Kualitatif, dan R\&D. Bandung. Alfabeta.

Tafsir, Ahmad, 2000. "Pentingnya Pendidikan Agama dalam Keluarga", dalam Ahmad tafsir (ed), Pendidikan Agama dalam Keluarga, (Bandung: Remaja Rosdakarya.

Ulwan, Abdullah, 1893. Tarbiyatul Aulad fi al-Islam, Juz. II, Beirut: Dar as Salam. Tarbiyatul Aulad fi al-Islam, Juz. II, Beirut: Dar as Salam.

Untung, Moh. Slamet, 2005. Muhammad Sang Pendidik, Semarang : Pustaka Rizki Putra.

2005. Muhammad Sang Pendidik, Semarang: Pustaka Rizki Putra.

Jurnal Pendidikan Agama Islam IAIN Syekh Nurjati Cirebon 